\title{
Startups and reasons for their failure
}

\author{
Lenka Mikle \\ University of Economics, Faculty of Business Management, Department of Management, 85235 \\ Dolnozemská cesta 1 Bratislava, Slovakia \\ lenka.mikle@euba.sk
}

\begin{abstract}
The world is one big agreement. When we are going to school, when we are going to work or shopping. We can meet some type of agreement totally everywhere. In shop, we cannot take a thing without remittance. In school, we cannot take the best grades without knowledge and in work, we cannot take a financial reward without any added services. Business environment is very complicated, especially in these days. All trade activities are affected by a lot of factors, which are unpredictable. For customer is the most important right solution for their needs and for company is the most important find to way how to satisfy customer's need. The main purpose of this article is offering a view on small, beginning enterprise trying to provide customers something special through innovative product or used revolutionary technologies - the startup. On the other hand, as we know, minimum amount of startups can survive the first four years. Why is it so?
\end{abstract}

\section{Introduction}

Human individuality provides countless views of the world. Every person sees him differently. The physicist sees it as a set of laws that secure things around us. The doctor sees it as a mixture of human bodies, each one being identical and original. The mathematician sees it as a set of ubiquitous numbers. But what is the world really like? Dynamic, weird, unique and authentic. No action will take place again under the same conditions.

The current global economy is being commanded by large multinationals that set up smaller subsidiaries in different countries. The purpose of this business can be to gain a power position in the market or diversify risk. Small and medium-sized enterprises, which have a large representation in each country, are also helping to develop the economy. They are the driving force of any economy, bringing with them a number of positives. The last decade in the economic world has brought many innovations, new technologies and startups. The word, which refers to a small starting business with an innovative idea, began to spread from American Silicon Valley. This valley was the cradle for today's famous businesses, including Apple, eBay, NVIDIA Corporation, Intel, Google and Yahoo!.

Startups are among the greatest pioneers of business endeavour in the world economy. They bring innovative products and new approaches to customers, grow exponentially, become global enterprises. 


\subsection{Attribute of a startup}

An American entrepreneur and author of many startups, Eric Ries, is undoubtedly one of the best-known authors on startups. Eric Ries has been involved in the creation of several startups, including IMVU. He advised business and product strategies for venture capital firms. Eric Ries [1] describes startup as an attractive form of business that gives space for expectations to grow but can also be disappointing. He sees startup as an institution made up of people whose main goal is to create a new product or service in truly extreme and unstable conditions. According to Eric Ries, startup is an absolutely human business, not a business based only on a product, technology or innovative idea.

Another expert for startup is Steve Blank [2], who has revolutionized business practice in business and innovation. Customer preference was a key factor in the search for a successful business model that came up with the topic of startups. Steve Blank and bob Dorf have worked on a book publication called The Startup Founder Handbook [3], in which they clearly and categorize startup as a temporary organization looking for a scalable, repeatable and profitable business model. He found that startups are not small versions of large companies, because large companies operate according to business models, startups are still looking for them. Startups on their business path have adopted product development methodology, product launches, life cycle phases and identical processes taught in entrepreneurship schools. Blank and Dorf examined in detail all too much the same reasons for startup failures. As a result, they came to the conclusion that startups need their own business tools, different from those used to manage large, existing businesses, because each startup moves in unknown and unexplored waters. The vision of startup is a series of untested hypotheses that require customer response. Information or data should be refreshed on a regular basis in days or weeks and not in months or years. The important thing is to keep it up-to-date and not waste the time spent unnecessarily improving a product that customers don't really want.

Also interesting is the view of the American businessman Paul Graham, who is a cofounder od Y Combinator. In 1995, together with Robert Morris, he founded Viaweb, the first SaaS company to become Yahoo!. In 1998 Y Combinator is a startup venture capital company. The main goal is to help startups bridge the first, most difficult phase of their existence and then introduce startups to larger investors or businesses interested in acquisition [4]. Paul Graham [5] from his own experience describes startup as a business designated for rapid growth. Starting a business by itself does not mean setting up a startup. There is also no need for startups to start working on technology or take advantage of venture capital funding or have a fancy exit plan. The only important thing about startup is growth. Everything else that we associate with startups results from growth.

The answer to the question "what is startup" can be provided by a person who has experienced the pitfalls of this business. Wil Schroter [6] founder of a web portal that gathers news from the startup environment, defines startup as the embodiment of the dreams of each founder. According to author, startup is the way from concept to reality, turning dreams into reality, which will be useful not only for the founder but also for the whole world.

The review of current literature has provided several points of view of startup and its main attributes. In addition, we can summarize that startup is a small business in unstable or extreme conditions that tries to reach consumers by providing a product that is not yet provided by any other competing business or was the founder of an innovative idea in industry. The business of each startup should be distinguished by its originality, which the startup can achieve through the use of original technology or creating a completely new need. In terms of startups, creating a new need is crucial, giving startup a competitive advantage in the industry. 


\subsection{Differences between startup and small or medium-sized enterprises}

Startup as a business unit could be compared to small, respectively to medium-sized enterprises. But how can we tell which business is startup and which is simply a small business? Are there clear differences between them or will we have to rely on our assumptions?

According to the new definition, small and medium-sized enterprises are defined mainly by the number of workers. Micro enterprises are defined as enterprises employing fewer than 10 persons and whose annual turnover or annual balance sheet amount does not exceed 2 million Eur. Small enterprises are defined as enterprises employing fewer than 5é persons and whose annual turnover or annual balance sheet amount does not exceed 10 million Eur [7]

According to the Slovak Business Agency (SBA), in 2018 small and medium-sized enterprises (SMEs) made up $99.9 \%$ of the total number of business entities. Of this figure, up to $73.2 \%$ of SMEs contributed to employment in the business economy and $54.6 \%$ of SMEs contributed to total value added.

According to the Statistical Office, 560521 business entities were active in 2018, of which up to 559841 were small and medium-sized enterprises [8].

The question arises, how to distinguish startup from small business? Number of employees? Annual turnover or annual balance sheet total? Let's take a look at the differences that are undoubtedly between these business entities. Every founder, whether we are talking about startup or small business, strives to maximize profits and minimize costs. We know startups that also compress the employment curve as low as possible and contribute to overall added value.

According to Pope [9] the difference between a startup and a small business is often subjective in terms of growth goals and revenue forecasts. Startups are primarily aimed at "market distortions" and seek to increase revenues at a rapid pace. On the other hand, small businesses often set long-term goals and stable growth in the existing market. The author also highlights the high risk of startups. Every startup tries to find out if their product or service will find its place in the market. Investing a lot of time and money in startup is a huge risk.

The difference between a startup and a small business can also be seen from investor's perspective - investors have different expectations when providing funds. In the case of investing in a small business, the investor expects a slow repayment of the debt incurred. A small business poses less risk to the investor's capital in the long run but needs to be aware of a lower profit than the startup can generate. If the investor decides to put his money into the startup, he uses the portfolio investment that enables risk diversification [10].

Investing in every single type of business carries a certain amount of uncertainty. However, putting funds into startups is a bit riskier because the founder has only a business idea, no specific product or service. In the long run, a small business seeks to stay on the market, generate slow-growing profits and still be on the positive side. The return on funds from this type of business is more secure but should be expected in the longer term. Providing startup money is riskier because of having only an idea but if a business idea is taken up and successful in the market, the repayment of the deposit can be in a much shorter time frame. In the long run, however, it is more interesting for a startup to rocket up and make unimaginable profits or to be "bought" by a large, established company that can replace one of its departments, such as Research and Development.

Another difference between a small business and a startup can be seen in the question of the legal form companies can choose. Small and medium-sized enterprises have the largest representation in the form of a limited liability company. In 2017, the Commercial Code of the Slovak Republic was amended to a new legal form, which allows startups to use the legal possibilities that the state allow them. 


\subsection{Reasons of startups failure}

The founders are very happy to share their advices, tips and experiences about the success of startups. Otherwise, if the startup does not make such profound profits? The American portal CB insights, which collects and analyses a huge amount of data using algorithms and data visualization, was engaged in this reverse side. The main task of the portal is to provide answers to important strategic questions and thus to provide data that enable easier, not only strategic, decision-making.

Based on the information gathered, CB Insingths [11] compiled a ranking of the most common factors of failure. The survey was conducted on 101 startups, which unfortunately could not resist the pitfalls of the startup environment.

The most common cause of failure is the no need of product in up to $42 \%$ of cases. The founder of the startup is firmly convinced of the originality and innovativeness of the product and if it comes to production without prior analysis of customer segments, the product may not find the right feedback from consumers. Startup will not help great technology, excellent data on customer buying behaviour, expertise of team members if it does not address the current market need.

Another serious reason for failure is the lack of capital. Money and time are limited not only in startups, but their prudent distribution is important. Up to $29 \%$ of startups cited the misapplication of capital as a source of their failure.

The third most important reason for a startup failure is to build the wrong team. A diverse team with different experiences has often been cited as critical to overall success. The founders are aware of the missing or inadequately assembled team. When starting a business, the founder is confident and do not feel the need to share their initial enthusiasm with other team members, but over time, with increasing activities, tasks and roles will be misaligned. Team question was crucial for up to $23 \%$ of startups.

Poor marketing may also be an interesting factor. Knowing your customer segment, reaching out to it and delivering the right product is one of the most important skills of a successful startup. Know-how to attract attention and turn non-customers into customers. The cause of the failure occurred when startup was unable to launch its product. The founders did not use the idea of proper product promotion.

Burnout is often a serious problem. The work-life balance cannot be overlooked indefinitely. This was cited by $8 \%$ of startups as the cause of the failure. Being able to respond correctly in a dead end, reorienting your mind from loss to profits is considered equally important for success or prevention of burnout. It is in this situation that we can draw attention to the necessity of the tam, given the possible division of competences, which would largely prevent burnout.

The first online publication on startups in Europe can provide an unusual look at the failure factors. The authors have provided an overview of all startups since October 2010. The authors of the articles are particularly interested in technological startups., provide readers with analyses, interviews with the founders of individual startups, or news from the startup environment. Startups are broken down by country. They also provide important information and updates for potential startup founder. The author Arnaud [12] created a ranking of the ten most important reasons for startup failures, many of the causes are the same as those provided by CB Insights by the public, but a few are different and meaningful. The author advises companies in commodity trading and has established several companies during his business life.

An important cause of failure can be attributed to founders who are looking into their product and unwillingly receive product feedback and criticism. It is essential to realize who the product is, whether it is the founder or the consumer. Without accepting customer feedback, startup can hardly think of success in the industry. The founder may not be willing to publish a prototype for several reasons, for example is not sufficiently prepared 
or is concerned about competition. But without first introducing the product, the founder will never know the response and feedback from customers.

The last most common factor of startup failure may be incorrect timing. Some startups launch products when the right technology is not yet available. It may be fatal for a startup to come up with a product that is not ready for the market or customers. It is essential to capture the right moment to launch the product.

\section{Methods}

The aim of the title is to provide a view of startup as a business entity, which is extremely important for the economic environment, but largely threatened by factors that will often not allow it to survive on the market.

The main goal of this article is to provide an overview of the most common and most important factors affecting the life of a startup. The main objective of the article is supported by a several intermediate goals:

- an overview of current opinions on startup from several experts who act in the startup environment as an investor, co-founders of startup or scientists,

- the differences between a startup and a small business, given that in some case it may be difficult to distinguish between these two business entities.

This article serves as a literature search for readers by providing the most up-to-date opinions of current experts on the issue being addressed and allowing further questions to be addressed.

\section{Results}

As we surely know, startup is a small, beginning enterprise existing in extremely unstable conditions. The main idea of startup is providing innovative product or service. Every startup should try to open a blue ocean - segment of customers who are not served by existing business in the market. The best situation would be to create a new need that customers could appreciate.

In the case of startup, we should be aware of the differences that distinguish it from a small business. The first main difference is innovation because a small business does not require innovation as the same level as startup, for which this feature is key. Another difference is the rate of profit, every entrepreneur is trying to maximize profits and minimize costs, but startup is expected to achieve exponential revenue growth. The vision can make the difference between a startup and a small business. The small business strives to be active in the market for as long as possible, to generate constant profits and to maintain its customer segment. Startup aims to create a boom, gain exponential growth, sells as many products as possible and then be bought by a large company.

Based on the research created by the CB insights web portal, it can be argued that the most common causes of startup failures are lack of experience, insufficient marketing, lack of funds, competition and the founder's unwillingness to receive feedback.

\section{Discussion}

The biggest problem for small and medium-sized enterprises is access to capital in the initial phase of business, which can be fatal for startups. For a more efficient functioning of the national economy, attention must also be paid to smaller business entities, startups, which however, rarely survive without help. Provide support and accept their market survival efforts. 
Microenterprises, small and medium-sized enterprises contribute greatly to the proper functioning of each country's economy They create jobs, thereby reducing the level of unemployment and contributing to GDP. All of these benefits also apply to startups, which ranks among microenterprises by the number of employees.

At the end of this article we can express the importance of startups, small and mediumsized enterprises, support all government institutions for increased support of these enterprises.

\section{References}

1. RIES, E. The Lean Start-up. How Today's Entrepreneurs Use Continuous Innovation to Create Radically Successful Businesses. 1. edit. New York: Crown Business. 2011. 468s. ISBN 978-0-307-88791-7

2. BLANK, S. About Steve. 2015. [online]. Available on internet https://steveblank.com/about/

3. BLANK, S. - DORF, B. The Startup Owner's Manual : The Step-by-Step Guide for Building a Great Company. 1. vyd. Pescadero : K\&S Ranch, Inc. 2012. 182s. ISBN 978-0-9849993-7-8

4. GRAHAM, P. About Y Combinator. 2014. [online]. Available on internet https://www.ycombinator.com/about/

5. PAUL GRAHAM. Want to start a startup ? 2012. [online]. Available on internet http://www.paulgraham.com/growth.html

6. McGOWAN, E. (2018). What is a Startup Company, Anyway? Available on internet $<$ https://www.startups.com/library/expert-advice/what-is-a-startup-company>

7. EUROPEAN COMMISSION. (2006). New Definition of small and medium-sized enterprises : User Manual and Model Statement. Online:

$<$ https://www.unms.sk/swift_data/source/dokumenty/technicka_normalizacia/msp/def. $\%$ 20podnikov-sme_user_guide_sk.pdf

8. SLOVAK BUSINESS AGENCY. (2019). Správa o stave malého a stredného podnikania v Slovenskej republike v roku 2018. Available on internet $<\mathrm{http}: / /$ www.sbagency.sk/sites/default/files/sprava_o_stave_msp_2018_aktualizovane .pdf $>$

9. POPE, E. K. (2020). Startup vs Small Business : What's the Real Difference ? Available on internet $<$ https://www.fundera.com/blog/startup-vs-small-business $>$

10. STEPHENS, H. (2018). What's the Difference Between a Small Business and a Startup? Available on internet $<$ https://www.smartcompany.com.au/startupsmart/advice/difference-between-smallbusiness-startup/>

11. ARNAUD, B. The 10 Most Common Reasons why Startups Fail. 2018. [online]. Available on internet https://www.eu-startups.com/2018/09/the-10-most-commonreasons-why-startups-fail/ 